Editorial

\title{
Special Issue of the Manufacturing Engineering Society (MES)
}

\author{
Eva María Rubio * (D) and Ana María Camacho
}

Department of Manufacturing Engineering, Industrial Engineering School, Universidad Nacional de Educación a Distancia (UNED), St/Juan del Rosal 12, E28040 Madrid, Spain; amcamacho@ind.uned.es

* Correspondence: erubio@ind.uned.es; Tel.: +34-913-988-226

Received: 24 October 2018; Accepted: 29 October 2018; Published: 31 October 2018

check for updates

\begin{abstract}
Research in the field of materials is very broad, ranging from studies on the structure and properties at the atomic or molecular level to the most complex or sophisticated applications that can be done with them, as well as studies about other aspects related to their processing, use or management. The Special Issue of the Manufacturing Engineering Society (MES), published in the Section "Manufacturing Processes and Systems" of the journal Materials, focuses, mainly, on the applications and key processing aspects of materials, collecting a set of 48 original papers focused on the field of manufacturing engineering and materials processing.
\end{abstract}

Keywords: additive manufacturing and 3D printing; advances and innovations in manufacturing processes; sustainable and green manufacturing; manufacturing systems: machines; equipment and tooling; metrology and quality in manufacturing; Industry 4.0; product lifecycle management (PLM) technologies; production planning; risks

The Special Issue of the Manufacturing Engineering Society (MES), published in the Section "Manufacturing Processes and Systems" of the journal Materials, was born as an initiative from the Manufacturing Engineering Society of Spain, with the aim to spread outstanding works in which the latest cutting-edge advances in the field of manufacturing engineering and materials processing have been presented.

This Special Issue explored the evolution of traditional manufacturing models towards the new requirements of the Manufacturing Industry 4.0; publishing, finally, 48 papers (47 research papers and one concept paper) in the main topics covered by this Special Issue, concretely in: additive manufacturing and 3D printing; advances and innovations in manufacturing processes; manufacturing systems: machines, equipment and tooling, metrology and quality in manufacturing; product lifecycle management (PLM) technologies; and manufacturing engineering and society.

Likewise, in some of them, without being the main or most outstanding subjects of the work, the following topics have been also addressed: sustainable and green manufacturing; manufacturing of new materials; manufacturing automation; design, modeling and simulation in manufacturing engineering; and production planning.

Contributions on emerging methods and technologies, such as those related to additive manufacturing and 3D printing [1-14], have been very numerous, which is not surprising as they are technologies with a lot of potential.

The number of contributions in the "advances and innovations in manufacturing processes" field has been very remarkable as well, where outstanding works have been presented in the following areas: machining [15-24], forming [25-30], moulding [31], welding [32,33], and non-traditional manufacturing processes [34-38]. 
No less important, as a whole, are the works on: manufacturing systems: machines, equipment and tooling [39-42], metrology and quality in manufacturing [43-45], product lifecycle management (PLM) technologies [46] and, risks, within the topic "manufacturing engineering and society" [47,48].

The Special Issue has been an excellent means of exposing some of the main current lines of research of members and collaborators of the MES, promoting the internationalization of their results and the presence of the MES itself in the international scientific-technical landscape, widely fulfilling the aims initially proposed.

It is remarkable how many readings and downloads of papers belonging to this Special Issue have been done, after only three months since the publication of the first work, showing the great interest that all these topics arouse in readers of the journal Materials; particularly topics related to the processing of materials.

\section{In Memoriam}

We want this Special Issue to serve as a posthumous tribute to our colleague and friend Mariano Marcos Bárcena, who participated very actively in the genesis of this thrilling project, and whose contribution to manufacturing engineering is present in this Special Issue, both explicitly, in a concrete work, and implicitly, in several papers by his research group from the University of Cadiz who have kept working on the investigation lines promoted by him.

Conflicts of Interest: The authors declare no conflict of interest.

\section{References}

1. Quiñones, D.; Soler-Egea, D.; González-Pérez, V.; Reibke, J.; Simarro-Mondejar, E.; Pérez-Feito, R.; García-Manrique, J.; Crispín, V.; Moratal, D. Open Source 3D Printed Lung Tumor Movement Simulator for Radiotherapy Quality Assurance. Materials 2018, 11, 1317. [CrossRef] [PubMed]

2. Valerga, A.; Batista, M.; Salguero, J.; Girot, F. Influence of PLA Filament Conditions on Characteristics of FDM Parts. Materials 2018, 11, 1322. [CrossRef] [PubMed]

3. Rodríguez-Panes, A.; Claver, J.; Camacho, A. The Influence of Manufacturing Parameters on the Mechanical Behaviour of PLA and ABS Pieces Manufactured by FDM: A Comparative Analysis. Materials 2018, 11, 1333. [CrossRef] [PubMed]

4. Pérez, M.; Medina-Sánchez, G.; García-Collado, A.; Gupta, M.; Carou, D. Surface Quality Enhancement of Fused Deposition Modeling (FDM) Printed Samples Based on the Selection of Critical Printing Parameters. Materials 2018, 11, 1382. [CrossRef] [PubMed]

5. Ruiz, J.; Cortina, M.; Arrizubieta, J.; Lamikiz, A. Study of the Influence of Shielding Gases on Laser Metal Deposition of Inconel 718 Superalloy. Materials 2018, 11, 1388. [CrossRef] [PubMed]

6. Sodupe-Ortega, E.; Sanz-Garcia, A.; Pernia-Espinoza, A.; Escobedo-Lucea, C. Accurate Calibration in Multi-Material 3D Bioprinting for Tissue Engineering. Materials 2018, 11, 1402. [CrossRef] [PubMed]

7. Cordovilla, F.; García-Beltrán, Á.; Garzón, M.; Muñoz, D.; Ocaña, J. Numerical-Experimental Study of the Consolidation Phenomenon in the Selective Laser Melting Process with a Thermo-Fluidic Coupled Model. Materials 2018, 11, 1414. [CrossRef] [PubMed]

8. Rabionet, M.; Polonio, E.; Guerra, A.; Martin, J.; Puig, T.; Ciurana, J. Design of a Scaffold Parameter Selection System with Additive Manufacturing for a Biomedical Cell Culture. Materials 2018, 11, 1427. [CrossRef] [PubMed]

9. Minguella-Canela, J.; Morales Planas, S.; Gomà Ayats, J.; de los Santos López, M. Assessment of the Potential Economic Impact of the Use of AM Technologies in the Cost Levels of Manufacturing and Stocking of Spare Part Products. Materials 2018, 11, 1429. [CrossRef] [PubMed]

10. Prado-Cerqueira, J.; Camacho, A.; Diéguez, J.; Rodríguez-Prieto, Á.; Aragón, A.; Lorenzo-Martín, C.; Yanguas-Gil, Á. Analysis of Favorable Process Conditions for the Manufacturing of Thin-Wall Pieces of Mild Steel Obtained by Wire and Arc Additive Manufacturing (WAAM). Materials 2018, 11, 1449. [CrossRef] [PubMed] 
11. Park, K.; Kim, K.; Lee, S.; Lim, G.; Kim, J. Fabrication of Polymer Microstructures of Various Angles via Synchrotron X-ray Lithography Using Simple Dimensional Transformation. Materials 2018, 11, 1460. [CrossRef] [PubMed]

12. Pérez-Pérez, M.; Gómez, E.; Sebastián, M. Delphi Prospection on Additive Manufacturing in 2030: Implications for Education and Employment in Spain. Materials 2018, 11, 1500. [CrossRef] [PubMed]

13. Quiñones, D.; Ferragud-Agulló, J.; Pérez-Feito, R.; García-Manrique, J.; Canals, S.; Moratal, D. A Tangible Educative 3D Printed Atlas of the Rat Brain. Materials 2018, 11, 1531. [CrossRef] [PubMed]

14. Buj-Corral, I.; Bagheri, A.; Petit-Rojo, O. 3D Printing of Porous Scaffolds with Controlled Porosity and Pore Size Values. Materials 2018, 11, 1532. [CrossRef] [PubMed]

15. Salguero, J.; Vazquez-Martinez, J.; Sol, I.; Batista, M. Application of Pin-On-Disc Techniques for the Study of Tribological Interferences in the Dry Machining of A92024-T3 (Al-Cu) Alloys. Materials 2018, 11, 1236. [CrossRef] [PubMed]

16. Sánchez Hernández, Y.; Trujillo Vilches, F.; Bermudo Gamboa, C.; Sevilla Hurtado, L. Experimental Parametric Relationships for Chip Geometry in Dry Machining of the Ti6Al4V Alloy. Materials 2018, 11, 1260. [CrossRef] [PubMed]

17. Gómez-Parra, Á.; Sanz, A.; Gámez, A. Evaluation of the Functional Performance in Turned Workpieces: Methodology and Application to UNS A92024-T3. Materials 2018, 11, 1264. [CrossRef] [PubMed]

18. Fernandez-Vidal, S.; Fernandez-Vidal, S.; Batista, M.; Salguero, J. Tool Wear Mechanism in Cutting of Stack CFRP/UNS A97075. Materials 2018, 11, 1276. [CrossRef] [PubMed]

19. Álvarez, Á.; Calleja, A.; Arizmendi, M.; González, H.; Lopez de Lacalle, L. Spiral Bevel Gears Face Roughness Prediction Produced by CNC End Milling Centers. Materials 2018, 11, 1301. [CrossRef] [PubMed]

20. Rubio, E.; Villeta, M.; Valencia, J.; Sáenz de Pipaón, J. Cutting Parameter Selection for Efficient and Sustainable Repair of Holes Made in Hybrid Mg-Ti-Mg Component Stacks by Dry Drilling Operations. Materials 2018, 11, 1369. [CrossRef] [PubMed]

21. Navarro-Mas, M.; García-Manrique, J.; Meseguer, M.; Ordeig, I.; Sánchez, A. Delamination Study in Edge Trimming of Basalt Fiber Reinforced Plastics (BFRP). Materials 2018, 11, 1418. [CrossRef] [PubMed]

22. De Agustina, B.; Marín, M.; Teti, R.; Rubio, E. Analysis of Force Signals for the Estimation of Surface Roughness during Robot-Assisted Polishing. Materials 2018, 11, 1438. [CrossRef] [PubMed]

23. Caggiano, A.; Improta, I.; Nele, L. Characterization of a New Dry Drill-Milling Process of Carbon Fibre Reinforced Polymer Laminates. Materials 2018, 11, 1470. [CrossRef] [PubMed]

24. Martín, M.; Cano, M.; Castillo, G.; Herrera, M.; Martín, F. Influence of Milling Parameters on Mechanical Properties of AA7075 Aluminum under Corrosion Conditions. Materials 2018, 11, 1751. [CrossRef] [PubMed]

25. Silva, D.; Silva, C.; Bragança, I.; Nielsen, C.; Alves, L.; Martins, P. On the Performance of Thin-Walled Crash Boxes Joined by Forming. Materials 2018, 11, 1118. [CrossRef] [PubMed]

26. Han, S.; Shu, X.; Shu, C. Study on Near-Net Forming Technology for Stepped Shaft by Cross-Wedge Rolling Based on Variable Cone Angle Billets. Materials 2018, 11, 1278. [CrossRef] [PubMed]

27. Sabater, M.; Garcia-Romeu, M.; Vives-Mestres, M.; Ferrer, I.; Bagudanch, I. Process Parameter Effects on Biocompatible Thermoplastic Sheets Produced by Incremental Forming. Materials 2018, 11, 1377. [CrossRef] [PubMed]

28. Medina-Sanchez, G.; Garcia-Collado, A.; Carou, D.; Dorado-Vicente, R. Force Prediction for Incremental Forming of Polymer Sheets. Materials 2018, 11, 1597. [CrossRef] [PubMed]

29. Linke, M.; García-Manrique, J. Contribution to Reduce the Influence of the Free Sliding Edge on Compression-After-Impact Testing of Thin-Walled Undamaged Composites Plates. Materials 2018, 11, 1708. [CrossRef] [PubMed]

30. Morales-Palma, D.; Borrego, M.; Martínez-Donaire, A.; Centeno, G.; Vallellano, C.; Morales-Palma, D.; Borrego, M.; Martínez-Donaire, A.J.; Centeno, G.; Vallellano, C. Optimization of Hole-Flanging by Single Point Incremental Forming in Two Stages. Materials 2018, 11, 2029. [CrossRef] [PubMed]

31. Ferrer, I.; Vives-Mestres, M.; Manresa, A.; Garcia-Romeu, M.L. Replicability of Ultrasonic Molding for Processing Thin-Wall Polystyrene Plates with a Microchannel. Materials 2018, 11, 1320. [CrossRef] [PubMed]

32. Pradeep Kumar, J. Effect of Temperature Distribution in Ultrasonically Welded Joints of Copper Wire and Sheet Used for Electrical Contacts. Materials 2018, 11, 1010. [CrossRef] [PubMed]

33. Souto, J.; Ares, E.; Alegre, P.; Cerqueiro, J. Methodology to Reduce Distortion Using a Hybrid Thermal Welding Process. Materials 2018, 11, 1649. [CrossRef] [PubMed] 
34. Sanchez, J.; Conde, A.; Arriandiaga, A.; Wang, J.; Plaza, S. Unexpected Event Prediction in Wire Electrical Discharge Machining Using Deep Learning Techniques. Materials 2018, 11, 1100. [CrossRef] [PubMed]

35. Arrizubieta, J.; Cortina, M.; Ruiz, J.; Lamikiz, A. Combination of Laser Material Deposition and Laser Surface Processes for the Holistic Manufacture of Inconel 718 Components. Materials 2018, 11, 1247. [CrossRef] [PubMed]

36. Wachulak, P.; Duda, M.; Fok, T.; Bartnik, A.; Wang, Z.; Huang, Q.; Sarzyński, A.; Jancarek, A.; Fiedorowicz, H. Single-Shot near Edge X-ray Fine Structure (NEXAFS) Spectroscopy Using a Laboratory Laser-Plasma Light Source. Materials 2018, 11, 1303. [CrossRef] [PubMed]

37. Mayuet Ares, P.; Vázquez Martínez, J.; Marcos Bárcena, M.; Gámez, A. Experimental Study of Macro and Microgeometric Defects in Drilled Carbon Fiber Reinforced Plastics by Laser Beam Machining. Materials 2018, 11, 1466. [CrossRef] [PubMed]

38. Caiazzo, F.; Alfieri, V. Simulation of Laser Heating of Aluminum and Model Validation via Two-Color Pyrometer and Shape Assessment. Materials 2018, 11, 1506. [CrossRef] [PubMed]

39. Bader, A.; Meiners, F.; Tracht, K. Accelerating High-Throughput Screening for Structural Materials with Production Management Methods. Materials 2018, 11, 1330. [CrossRef] [PubMed]

40. Gallego García, S.; García García, M. Design and Simulation of Production and Maintenance Management Applying the Viable System Model: The Case of an OEM Plant. Materials 2018, 11, 1346. [CrossRef] [PubMed]

41. Romero Subirón, F.; Rosado Castellano, P.; Bruscas Bellido, G.; Benavent Nácher, S. Feature-Based Framework for Inspection Process Planning. Materials 2018, 11, 1504. [CrossRef] [PubMed]

42. Vargas, J.; Calvo, R. Joint Optimization of Process Flow and Scheduling in Service-Oriented Manufacturing Systems. Materials 2018, 11, 1559. [CrossRef] [PubMed]

43. Brosed, F.; Zaera, A.; Padilla, E.; Cebrián, F.; Aguilar, J. In-Process Measurement for the Process Control of the Real-Time Manufacturing of Tapered Roller Bearings. Materials 2018, 11, 1371. [CrossRef] [PubMed]

44. Ontiveros, S.; Jiménez, R.; Yagüe-Fabra, J.; Torralba, M. Analysis of Surface Extraction Methods Based on Gradient Operators for Computed Tomography in Metrology Applications. Materials 2018, 11, 1461. [CrossRef] [PubMed]

45. García, J.C.; Sanz Lobera, A.; Maresca, P.; Pareja, T.F.; Wang, C. Some Considerations about the Use of Contact and Confocal Microscopy Methods in Surface Texture Measurement. Materials 2018, 11, 1484. [CrossRef] [PubMed]

46. Camarillo, A.; Ríos, J.; Althoff, K.-D. Product Lifecycle Management as Data Repository for Manufacturing Problem Solving. Materials 2018, 11, 1469. [CrossRef] [PubMed]

47. Brocal, F.; González, C.; Reniers, G.; Cozzani, V.; Sebastián, M.; Brocal, F.; González, C.; Reniers, G.; Cozzani, V.; Sebastián, M.A. Risk Management of Hazardous Materials in Manufacturing Processes: Links and Transitional Spaces between Occupational Accidents and Major Accidents. Materials 2018, 11, 1915. [CrossRef] [PubMed]

48. Van Nunen, K.; Swuste, P.; Reniers, G.; Paltrinieri, N.; Aneziris, O.; Ponnet, K. Improving Pallet Mover Safety in the Manufacturing Industry: A Bow-Tie Analysis of Accident Scenarios. Materials 2018, 11, 1955. [CrossRef] [PubMed]

(C) 2018 by the authors. Licensee MDPI, Basel, Switzerland. This article is an open access article distributed under the terms and conditions of the Creative Commons Attribution (CC BY) license (http://creativecommons.org/licenses/by/4.0/). 